\title{
Description and ecological notes on Isoctenus malabaris sp. nov. (Araneae, Ctenidae) from southern Brazil
}

\author{
Daniele Polotow ${ }^{1,2}$, Antonio D. Brescovit ${ }^{1} \&$ Ricardo Ott $^{3}$
}

\begin{abstract}
1. Laboratório de Artrópodes, Instituto Butantan, Av. Vital Brazil, 1500, 05503-900 São Paulo, SP, Brazil.(danielepolotow@yahoo.com.br; adbresc@terra.com.br)

2. Departamento de Zoologia, Instituto de Biociências, Universidade de São Paulo, Rua do Matão, travessa 14, 321, Cidade Universitária, 05508-900 São Paulo, SP, Brazil.

3. Museu de Ciências Naturais, Fundação Zoobotânica do Rio Grande do Sul, Rua Dr. Salvador França, 1427, 90690-000 Porto Alegre, RS, Brazil.(rott@fzb.rs.gov.br)
\end{abstract}

\begin{abstract}
A new species, Isoctenus malabaris, is described from southern Brazil. This spider was abundantly collected with pitfall traps at Araucaria Forests (Mixed Ombrophilous Forest) domain. The activity of this species was studied in three distinct habitats (primary and secondary forests and silvicultures) during 20 months. A bimodal seasonal activity pattern, of males, was observed. Abundance differences of this species between habitats were not significant.
\end{abstract}

KEYWORDS. Neotropical region, spiders, taxonomy, phenology.

RESUMO. Descrição e notas ecológicas de Isoctenus malabaris sp. nov. (Araneae, Ctenidae), do Sul do Brasil. Uma nova espécie, Isoctenus malabaris, é descrita para sul do Brasil. Espécimes desta aranha foram abundantemente coletados com armadilhas de queda em área de domínio da Floresta com Araucária (Floresta Ombrófila Mista). A atividade da espécie foi estudada em três hábitats distintos (florestas primárias e secundárias e silviculturas) ao longo 20 meses. Foi observado um padrão bimodal de atividades ao longo do ano, para espécimes machos. A diferença na abundância desta espécie entre os hábitats não foi significativa.

PALAVRAS-CHAVE. Região Neotropical, aranhas, taxonomia, fenologia.

Species of the genus Isoctenus Bertkau, 1880 are hunting spiders that constitute a conspicuous part of the ground-dwelling fauna of the central and southern Neotropical region. According to PLATNICK (2005), the genus currently includes seven species, five of them described from Brazil: Isoctenus foliifer Bertkau, 1880 and Isoctenus janeirus Walckenaer, 1837, from Rio de Janeiro, both based on immature specimens; Isoctenus masculus Mello-Leitão, 1939, based on a male from Santa Catarina; and, Isoctenus eupalaestrus Mello-Leitão, 1936 and Isoctenus strandi Mello-Leitão, 1936, both from the state of Paraná, based on a male and a female, respectively. The remaining two species, Isoctenus sigma Schenkel, 1953, from Venezuela and Isoctenus latevittatus Caporiacco, 1954, from French Guyana, do not seem to belong to this genus (LeTHINEN, 1967). Recently, Isoctenus coxalis (F. O. Pickard-Cambridge, 1902), described from southeastern Brazil, was transferred from Ctenus, and I. corymbus Polotow, Brescovit \& PellegatiFranco, 2005, the first cave-dwelling species, was described based on specimens from the state of Goiás, Brazil (PоLотоw et al., 2005). Isoctenus is diagnosed by the male palp with an embolus with a sinuous basal prolateral apophysis, median apophysis with two prominent projections, retrolateral tibial apophysis bifid with dorsal branch very developed and female epigynum with oval median plate, with posterior border projected, long lateral spurs and internally with a prominent ventral wall and spermathecae divided into a small head and a large base (PoLotow et al., 2005, figs. 1-4).

Recently, 390 adult specimens and 346 juveniles of an undescribed species of Isoctenus were found in pitfall trap samples implemented by the third author during his doctoral research in the state of Rio Grande do Sul, Brazil.
In this paper, we described this species and presented some observations regarding its habitat preferences and seasonal activity pattern.

\section{MATERIAL AND METHODS}

The material examined is deposited in the following institutions (curators in parenthesis): IBSP, Instituto Butantan, São Paulo (A. D. Brescovit); MCN, Museu de Ciências Naturais, Fundação Zoobotânica do Rio Grande do Sul, Porto Alegre (E. H. Buckup); MCTP, Museu de Ciências e Tecnologia da Pontifícia Universidade Católica do Rio Grande do Sul, Porto Alegre (A. A. Lise); MZSP, Museu de Zoologia, Universidade de São Paulo, São Paulo (R. Pinto da Rocha). All measurements are in millimeters. Descriptions follow PoLотоw et al. (2005). Acronyms: RTA, retrolateral tibial apophysis; AME, anterior median eyes; ALE, anterior lateral eyes; PME, posterior median eyes; PLE, posterior lateral eyes; $p$, prolateral; $r$, retrolateral; $d$, dorsal; $v$, ventral.

Ecological data were obtained from R. Ott doctoral thesis work (Programa de Pós-Graduação em Biociências - Zoologia, Faculdade de Biociências, Pontifícia Universidade Católica do Rio Grande do Sul - PUCRS). Sampled areas are located at "Centro de Pesquisas e Conservação da Natureza Pró-Mata", São Francisco de Paula, state of Rio Grande do Sul, Brazil (29 $28^{\prime} 21^{\prime \prime} \mathrm{S}$ $50^{\circ} 09^{\prime} 25^{\prime \prime} \mathrm{W}$ ). This site is located at "Serra Geral" (South Brazilian basaltic plateau) southeast border, at altitudes of approximately 600 to 900 meters. It is characterized mainly by Mixed Ombrophilous Forest (know as Brazilian pine forests or "Floresta com Araucária") with savannas, 
at higher altitudes, and Dense Ombrophilous Forests (Atlantic Rain Forest) in lower altitude slopes; climate is humid to very humid, with temperatures below $15^{\circ} \mathrm{C}$ during the winter season (BERTOLETTI \& TeIXEIRA, 1995). Six areas of three distinct forest habitats under different antropic influence were chosen for this study: two Araucaria angustifolia (Bert.) O. Kuntze (Araucariaceae) primary forests (earlier eventually exploited by some tree selective remotion), two secondary forests caracterized mainly by the presence of Tibouchina sellowiana (Chan.) Cong. (Melostomataceae), and two Pinus spp. (Pinaceae) silvicultures (see BAASKE, 2001). All sampled areas are in the Mixed Ombrophilous Forest domain (Araucaria angustifolia Forest) at altitudes around $900 \mathrm{~m}$. In each of the six areas, two $40 \mathrm{~m}$ transects were randomly chosen and, in every one, five pitfall traps of $10 \mathrm{~cm}$ diameter were installed $10 \mathrm{~m}$ apart from each other. The traps were filled with a $4 \%$ formalin solution with some drops of neutral detergent to break the superficial tension of fluid. Traps were kept permanently opened from IX.22.2000 to V.18.2002 and were emptied along 18 sampling dates (20 months) with an average of 33.4 days between sampling dates. Due to variations in number of days between sampling dates, the seasonal activity abundance of spiders at each sampling period is represented by a relation of the total spiders of sample period/total number of sampling days.

Spider abundance differences at the distinct habitats were tested using the Kruskal-Wallis test (non parametric ANOVA; $\alpha=0.05$ ). For this procedure, every habitat type was considered as treatment (primary, secondary and silviculture) and each area as a replicate in which were measured the mean number of adult spiders per trap, collected during the entire sample period. This test was performed using the software PAST version 1.44 (HAMMER et al., 2001).

\section{RESULTS}

\section{Isoctenus malabaris sp. nov. (Figs. 1-5)}

Types. Holotype $\sigma^{\top}$ and paratype $q$ from Centro de Pesquisas e Conservação da Natureza Pró-Mata (2928'21"'S 5009'25”W), São Francisco de Paula, Rio Grande do Sul, Brazil, I.02.2001, R. Ott col., deposited in MCN 39321; Paratypes: $\sigma^{\circ}, \propto$, deposited in IBSP 51957 and 51958; o o o deposited in MCTP 17142 and 17143; or of deposited in MZSP 25327 and 25328; all from the same locality, date and collector as the holotype.

Etymology. The specific name is an arbitrary combination of letters.

Diagnosis. Isoctenus malabaris sp. nov. resembles I. coxalis by the presence of an anterior and a posterior projections in the median apophysis of male palp (РоLOTоw et al., 2005, fig. 1) but differs from the remaining species of the genus by the long, curved and smooth dorsal branch and short and conical ventral branch of the RTA (Fig. 2), embolus with a conspicuous subtriangular basal prolateral projection, and by two very elongated projections in the median apophysis (Fig. 1) in the male palp. The females can be recognized by the oval median field with posterior border projected and by long lateral spurs (Fig. 3) on the female epigynum.

Description. Male (holotype). Carapace light brown. Chelicerae and endites light brown. Labium reddish. Sternum light brown with reddish border. Legs light brown with dark, large and transversal ventral lines on femora III-IV. Abdomen brown, with a slight dorsal arrow mark. Total length 10.10. Carapace 5.40 long, 4.30 wide. Clypeus 0.15 high. Eye diameters: AME 0.20; ALE 0.18; PME 0.25; PLE 0.27. Leg measurements: I: femur 4.60/ patella 2.01/ tibia $4.50 /$ metatarsus $4.00 /$ tarsus $1.90 /$ total 17.10 ; II: 4.00/ 1.80/3.90/3.50/ 1.60/ 14.80; III: 3.80/ 1.80/3.10/3.30/ 1.40/ 13.40; IV: 4.80/ 1.80/ 4.10/ 5.00/ 1.60/ 17.30. Leg formula: 4123. Leg spination: tibiae I v2-2-2-2-2, p0-1-0, r0; II v2-2-2-2-2, p0-1-0, r0; III v2-2-2, p1-1, r1-1; IV v2-22 , p1-1, r1-1; metatarsus I v2-2-2, p0, r0, II v2-2-2, p0, r0; III v2-2-2, p1-1-2, r1-1-2; IV v2-1-1-1-2, p1-1-2, r1-1-2. Palp: tibiae short, smaller than cymbium; tibial ventral apophysis very short; RTA with a long and smooth dorsal branch and short and conical ventral branch; cymbium distally elongated, with a rounded retrolateral basal projection, presenting a short and conical projection; embolus curved with a large base and a subtriangular basal prolateral apophysis; median apophysis curved and robust with two prominent projections; conductor hyaline and laminar, not involving the tip of embolus (Figs. 1, 2).

Female (MCN 39321). Coloration as in male, except chelicerae and endites reddish and sternum light brown. Epigynum reddish. Total length 11.20. Carapace 4.60 long, 3.90 wide. Clypeus 0.13 high. Eye diameters: AME 0.18; ALE 0.16; PME 0.23; PLE 0.20. Leg measurements: I: femur 3.40 / patella 1.80 / tibia 3.20 / metatarsus 2.30 / tarsus $1.90 /$ total 12.60; II: 3.10/ 1.70/2.80/2.20/1.30/ 11.10; III: 2.80/ 1.40/ 2.00/2.40/1.00/9.60;IV:3.50/1.70/3.20/3.90/1.30/13.60.Leg formula: 4123. Leg spination follows the male pattern, except: tibia I p0; II p0; metatarsus III r1-1-1; IV v2-2-2-2, r1-1-1. Median field oval, slightly elevated, posterior border projected. Lateral spurs long and rounded, anteriorly positioned (Fig. 3). Internal genitalia with the lateral spurs covering the distal area of the copulatory ducts; copulatory ducts elongated and sinuous; spermathecae large and curved, with distal and basal regions narrowed; fertilization ducts short and curved (Figs. 4, 5).

Variation. Ten males: total length 7.50-9.30; carapace length 4.10-4.70; femur I 3.10-4.30; ten females: total length 8.20-14.20; carapace length 3.60-5.70; femur I 2.80-4.50.

Distribution. Rio Grande do Sul, Brazil.

Natural history. Isoctenus malabaris was one of the most common spider species recorded with pitfall traps at the sampled areas, with 736 specimens ( 245 males, 145 females and 346 immatures). The clearly identifiable dorsal abdominal pattern in this species, allow the easy identification, inclusively of immatures.

The mean catch numbers of adult specimens per trap showed great variation between areas (Fig. 6); no significant difference was found in these numbers among habitats $(\mathrm{H}=3.714$, d.f. $=2, P=0.156)$.

Males of this species were recorded during all year but they showed two clear activity peaks: a large one between October and January (spring begin until summer begin) and a less representative activity peak in March/ April (summer end until autumn begin) (Fig. 7). The 

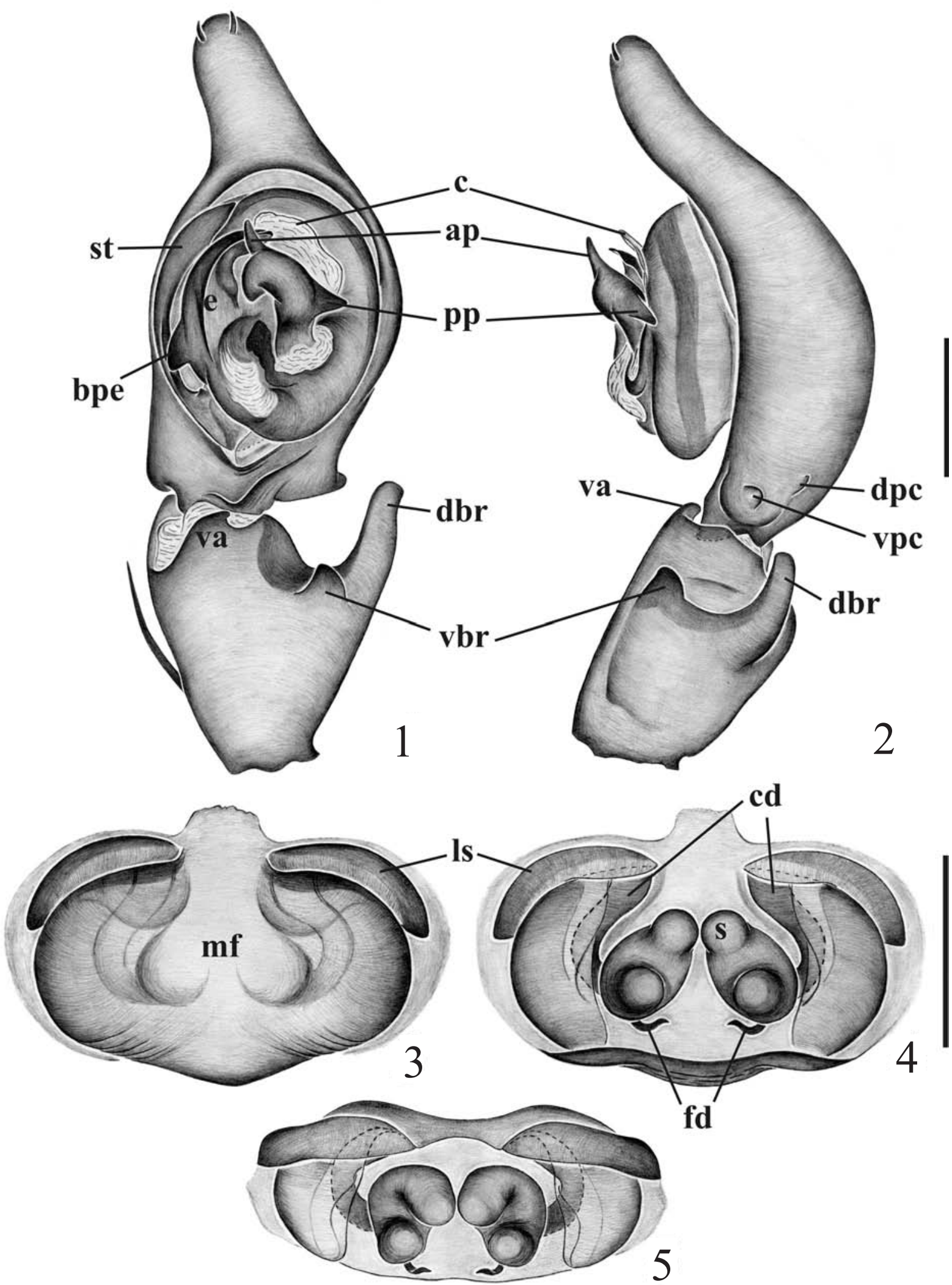

Figs. 1-5. Isoctenus malabaris sp. nov.: 1, 2, male, left palp, ventral and retrolateral views, respectively (ap, anterior projection of median apophysis; bpe, basal projection of embolus; c, conductor; dbr, dorsal branch of RTA; dpc, dorsal projection of cymbium; e, embolus; pp, posterior projection of median apophysis; st, subtegulum; va, ventral apophysis; vbr, ventral branch of RTA; vpc, ventral projection of cymbium). Scale line: $0.50 \mathrm{~mm}$. 3-5 female, epigynum, ventral, dorsal and anterior views respectively (cd, copulatory ducts; $\mathrm{fd}$, fertilization ducts; 1s, lateral spurs; mf, median field; s, spermathecae). Scale line: $0.50 \mathrm{~mm}$. 


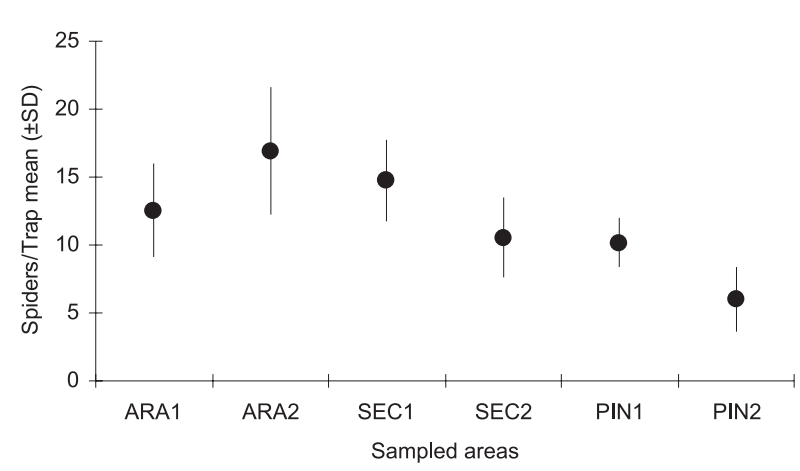

Fig. 6. Total numbers of adult specimens of Isoctenus malabaris sp. nov. collected in each areas of primary forest (ARA1, ARA2), secondary forest (SEC1, SEC2) and silviculture (PIN1, PIN2) at "Centro de Pesquisas e Conservação da Natureza Pró-Mata", São Francisco de Paula, State of Rio Grande do Sul, Brazil, collected from 22.IX.2000 to 18.V.2002.

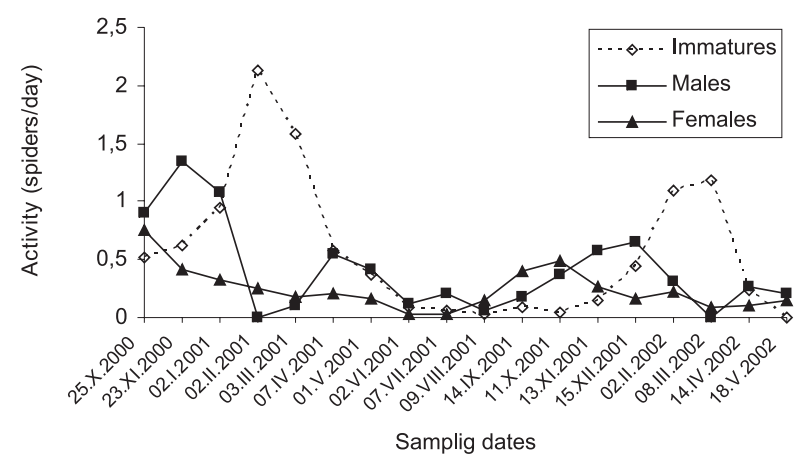

Fig. 7. Seasonal activity of specimes of Isoctenus malabaris collected at "Centro de Pesquisas e Conservação da Natureza PróMata", São Francisco de Paula, State of Rio Grande do Sul, Brazil, from 22.IX.2000 to 18.V.2002.

seasonal peaks of male specimens suggest a bivoltine phenology, with two reproductive periods during the year. However, the activity peaks of immature specimens (between spring end and summer end) provide another possible explanation for the supposed bimodal male activity pattern. The true reproductive peak is probably only the maximum activity peak of males (see Tretzel, 1954 apud Aitchinson, 1984); in this case, between October and January, with the posterior appearance of juveniles in the summer (Fig. 7). The second male activity peak, in March/April, is probably exclusively related with the last molt of immature specimens, when they reach sexual maturity. This conclusion is strongly sustained by the absence of a second immature peak after this period. Thus, males of this species show a sexual maturity peak in the middle of their first life year, (lower peak) and, at the end of their first life year they show a reproductive peak (maximum peak). Females of this species are also registered along the entire year. However, their activity shows a very remarkable reduction in May (autumn end) and an increase from August to January (winter end until summer begin), but with two distinct peaks in this period: a higher one in August/September and a smaller one in December/January. Unlikely in males, the activity of females possibly decreases at the middle of mating season (Fig. 7). As a small ctenid, but a fairly large spider, Isoctenus malabaris sp. nov. has probably a biennial life cycle as observed for lycosids (Dondale, 1977).

Other material examined. BRAZIL. Rio Grande do Sul: Barracão, O’, 8.V.2001, R. Ott \& L. Moura col. (MCN 33877); Derrubadas, Parque Estadual do Turvo, ơ, 19-22.X.2004, R. Ott et al. col. (MCN 38810); São Francisco de Paula (Centro de Pesquisas e Conservação da Natureza Pró-Mata), 3 ơ 2 우, 2.I.2001, (IBSP 51959-51962); 3 ơ, IX.23.2000 (MCN 39322); $2 \sigma^{2}$,, , X.25. 2000 (MCN 39323); 3 o', XI.23.2000 (MCN 39324); o, ㅇ, V.18.2002 (MCN 39325); 4 ơ, XI.23.2000 (MCN 39326); 2 , 02.II.2002 (MCN 39327); 2 ․, II.02.2002 (MCN 39328); 2 o, ㅇ, X.25.2000 (MCN 39329); 3 o', 25.X.2000 (MCN 39330); $2200^{3}, 132$ P, X. 25.2000- V.18.2002 (MCTP); all collected by R. Ott. (Fazenda Três Cachoeiras), +, II.3.1999, A. B. Bonaldo col. (MCN 30747); Canela, O’, VII.3.1965, A. A. Lise col. (IBSP 2952); Maquiné, Fundação Estadual de Pesquisa Agropecuária (FEPAGRO), 15 ơ , 57 \% , I.18-27.2002, Equipe Biota col. (IBSP 55078-55116). Santa Catarina: Blumenau (Parque Natural Municipal Nascentes do Garcia), 18 ơ, 34 ㅇ, I.21-28. 2003, Equipe Biota col. (IBSP 55931-55953).

Acknowledgements. We wish to thank Cristina A. Rheims and Adalberto J. Santos, both from Instituto Butantan, for helpful suggestions on the manuscript. This study was supported by CNPq (Conselho Nacional de Desenvolvimento Científico e Tecnológico), CAPES (Coordenação de Aperfeiçoamento de Pessoal de Nível Superior) and BIOTA FAPESP program (no. 99/05446-8) - The Biodiversity Virtual Institute Program (www.biotasp.org.br).

\section{REFERENCES}

Aitchinson, C. W. 1984. The phenology of winter-active spiders. Journal of Arachnology 12(3):249-271.

BAASKE, R. 2001. Vegetationskartierung des Forschungsgebietes Pró-Mata, Rio Grande do Sul, Brasilien, unter Verwendung von CIR-Luftbildern. Rottenburg, Fachhochschule Rottenburg, Hochschule für Forstwiirtschaft Schadenweilerhof. 1 CD-ROM.

Bertoletti, J. J. \& Teixeira, M. B. 1995. Centro de Pesquisas e Conservação da Natureza Pró-Mata. Divulgações do Museu de Ciências e Tecnologia 2:1-47.

Dondale, C. D. 1977. Life histories and distribution patterns of hunting spiders (Araneida) in an Ontario meadow. Journal of Arachnology 4(2):73-93.

Hammer, Ø.; Harper, D. A. T. \& Ryan, P. D. 2001. PAST: Palaeontological Statistics software package for education and date analysis. Paleontologia Eletronica 4(1):9.

Lethinen, P. T. 1967. Classification of the cribellate spiders and some allied families, with notes on the evolution of the soborder Arameomorpha. Annales Zoologici Fennici 4(3): 198-468

Platnick, N. I. 2005. The world spider catalog, version 6.0. American Museum of Natural History. Avaliable at: <http:// research.amnh.org/entomology/spiders/catalog/index.html>. Access on: 06.2005

Polotow, D.; Brescovit, A. D. \& Pellegatti-Franco, F. 2005. A redescription of Isoctenus coxalis (F. O. P. Cambridge, 1902) comb. nov. and description of I. corymbus, a new species of cave dwelling spider (Araneae, Ctenidae, Cteninae) from the state of Goiás, Brazil. Revista Ibérica de Aracnologia 10:37-42. 